Revista Iberoamericana, Vol. LXXXV, Núm. 267, Abril-Junio 2019, 651-653

\title{
NORMAS PARA LA PUBLICACIÓN DE ARTÍCULOS
}

Revista Iberoamericana publica artículos, notas y reseñas sobre crítica literaria y cultural latinoamericana. Es editada por el Instituto Internacional de Literatura Iberoamericana (IILI), el cual fue fundado en 1938 en la Ciudad de México por figuras como Alfonso Reyes y Pedro Henríquez Ureña, y actualmente tiene su sede en la Universidad de Pittsburgh, Pennsylvania.

Revista Iberoamericana se publica ininterrumpidamente desde la fundación del IILI y edita un volumen por año, que se organiza en cuatro números cuatrimestrales. Además de la tradicional edición en papel, Revista Iberoamericana ofrece una edición digital: http://revista-iberoamericana.pitt.edu/

Se considerarán para publicación en Revista Iberoamericana artículos originales, en español o portugués, que cumplan con las siguientes normas editoriales:

1) Revista Iberoamericana publica artículos pertenecientes a los socios del Instituto Internacional de Literatura Iberoamericana (IILI) o de autores invitados que participan en números especiales. En el caso de los números especiales, el coordinador del número debe ser socio del IILI.

2) Los artículos enviados a Revista Iberoamericana deben ser inéditos y no pueden estar en trámite de publicación por otra revista o medio.

3) La extensión de los artículos no puede exceder las 25 páginas (tamaño carta, $21.5 \times 28 \mathrm{~cm}$.), incluyendo bibliografía y citas, con letra Times New Roman, 12 puntos e interlineado de 2.0. Los envíos que no respeten esta extensión serán devueltos. Los manuscritos deben ser enviados como archivo electrónico, en formato Microsoft Word, a: iilisus@pitt.edu. No incluya su nombre y/o afiliación académica en el documento, dicha información de contacto debe 
aparecer en el cuerpo del correo electrónico. Eliminar otras referencias en el documento que puedan indicar, por implicación, la identidad del autor.

4) El artículo debe estar acompañado de un resumen (abstract) en español y otro en inglés, de 100 palabras como máximo cada uno, incluyendo además 5 palabras claves, también en español e inglés. El título del artículo debe aparecer en ambos idiomas. El resumen debe hacer explícito el objetivo de la investigación, los hallazgos, las conclusiones y la aportación al campo de estudios.

5) Las imágenes, fotografías, mapas e ilustraciones no forman parte de la extensión del artículo. Estos deben enviarse por separado en formato JPG y no pueden tener menos de 300 dpi. Al enviar imágenes, debe tenerse en cuenta que Revista Iberoamericana se publica en blanco y negro. Los autores deben asegurarse de que los derechos de uso de dichas imágenes estén vigentes y que tienen autorización para usarlos.

6) Los artículos deben ser compuestos siguiendo las normas de estilo del IILI que se encuentran disponibles en: www.iilionline.org/normas, así como las del MLA Handbook ( $8^{\text {th }}$ edition). Estas normas deben seguirse con la mayor exactitud posible a fin de facilitar el proceso de evaluación, corrección y edición. Con ellas se intenta mantener la precisión de lo escrito, facilitar la lectura y el acceso a las fuentes de información. Destacamos la norma específica de la Revista, de que todas las citas intertextuales deben figurar en español; el autor es responsable de las traducciones necesarias.

7) Revista Iberoamericana cumple un proceso de evaluación riguroso. Todas las contribuciones son revisadas inicialmente por el Director de Publicaciones o por un miembro del Consejo Editorial para determinar si corresponden a la línea editorial de la revista y si cumplen con los estándares académicos. Si este proceso inicial es satisfactorio, el manuscrito es evaluado a fondo por dos dictaminadores a través de un sistema de arbitraje de doble ciego. Dichos evaluadores pueden aceptar el artículo sin cambios, aceptarlo con sugerencias, solicitar cambios sustanciales o rechazarlo. En caso de discrepancia entre los dictaminadores, el artículo se remite a otra evaluación. Si el trabajo requiere cambios importantes, la nueva versión recibe una segunda lectura por parte de uno de los dictaminadores, y el autor debe enviar un correo electrónico explicando las modificaciones que ha realizado, antes de recibir una respuesta definitiva. 
8) La comunicación de los dictámenes tiene un plazo de entre tres y seis meses, y se realizará a través de una carta de aceptación, de aceptación con cambios o de rechazo, que será enviada a los autores por correo electrónico. Si el artículo requiere cambios, los autores tienen un plazo de dos semanas para hacer los mismos. Luego de evaluar los cambios, se informará al autor el resultado del proceso por medio de un correo electrónico. Es necesario que los autores mantengan su suscripción activa y vigente durante todo el proceso de edición.

9) Los artículos invitados, que fueron solicitados para ser incluidos en los números especiales, deben ser aprobados por el coordinador de dicho número especial, con la supervisión del Director de Publicaciones y/o el Consejo Editorial.

10) Revista Iberoamericana publica notas, es decir, artículos cuya extensión no excede las 12 páginas (tamaño carta, $21.5 \times 28 \mathrm{~cm}$.), incluyendo bibliografía y citas. Las notas deben tener un enfoque crítico sólido, y tratar sobre algún tema o problema puntual. Las notas deben ajustarse a los mismos requisitos de envío que los artículos, y son sometidas al mismo proceso de evaluación.

11) Las notas y los artículos aceptados reciben correcciones de estilo si es necesario para adaptarlos a los estándares de la Revista Iberoamericana.

12) Las opiniones expresas en los artículos publicados por el IILI pertenecen a su autor, quien será el único responsable de las mismas. 
